\title{
THE INVENTION OF MUSICAL ILLYRISM
}

\author{
STANISLAV TUKSAR \\ Hrvatska akademija znanosti i umjetnosti
}

\begin{abstract}
Izvleček: Star rimski izraz »Illiricum«, ki ga je Katoliška cerkev v 17. stoletju uporabljala za province Dalmacija, Hrvaška, Bosna in Slavonija, so ideologi hrvaškega narodnopreporodnega gibanja »ponovno izumili« $v$ tridesetih letih 19. stoletja kot nadnacionalni konstrukt. Izraz so v glasbi na Hrvaškem v 19. stoletju uporabljali tudi številni skladatelji, izvajalci, muzikologi, občinstvo in mediji.
\end{abstract}

Ključne besede: ilirizem, Hrvaška, južnoslovansko področje, glasba, koncept »kulturni narod«.

\begin{abstract}
The ancient Roman term "Illyricum", reintroduced by the Catholic Church in the seventeenth century to denote the provinces of Dalmatia, Croatia, Bosnia and Slavonia, was "re-invented" by the ideologists of the Croatian National Revival movement in the 1830s as a supra-national construct. It was also used in music by many composers, performers and musicologists, as well as broader audiences and public media in nineteenth-century Croatia.
\end{abstract}

Keywords: Illyrism, Croatia, South Slavic area, music, "cultural-national" concept.

In identifying the idea of "Illyrism" as applied in nineteenth-century Croatian musical culture, it seems useful to first present the genesis of the term itself and its usage in both Croatian and South-Slavic, as well as in the broader regional cultural and social history. In this, the long temporal development in its construction manifests a multi-layered character, unveiling the complex parallel structure of its sometimes elusive and vague denotations and meanings.

It is well known that the term itself, mostly in the form of the noun "Illyricum" $(\rightarrow$ Illyria Romana, Illyria Barbara), was used in ancient Rome to geographically denote its province from $167 \mathrm{BC}$ to $10 \mathrm{AD}$ along the eastern shores of the Adriatic Sea and its hinterlands. ${ }^{1}$ Between AD 10 and 35 Roman administrators dissolved the province of Illyricum and divided its lands between the new provinces of Pannonia and Dalmatia. After a long period of oblivion, at the dawn of the Modern Era the term once again started to be used extensively in documents and literature, during the late Renaissance within the humanist revival-of-Antiquity trends, and after the Tridentine Council within the

1 Katičić, "Ilirci i ilirski jezik", 681. 
Catholic Counter-Reformation movement, especially from the beginning of the seventeenth century onward. The term "Illyria" is more often found in texts written in Latin, but terms such as "Dalmatia" and "Slavonia" were also used as synonyms. ${ }^{2}$ In any case, it should be pointed out that during ancient Roman times the term was used to denote the indigenous Balkan population of the Illyrico-Celtic tribes such as the Liburnians, Dalmatians, Japods, Istrians, Pannonians and so on. From the early Modern Age it was used in a substantially different way: to denote the population with Slavic origins which, mixed with indigenous peoples, had started to gradually infiltrate and later dominate the area from the beginning of the seventh century. Thus a shift can be identified, by which it became customary to use the name of "Illyricum" for the territory, the term "Illyrians" for the population and the word "Illyric/Illyrian" as an adjective referring to the ethnicity, nationality and language of the corresponding population. This shift was given a decisive push on 10 December 1655, when the Roman Rota proclaimed that the physical space of Dalmatia seu Illyricum was "part of the territory which encompassed Dalmatia, Croatia, Bosnia and Slavonia". ${ }^{3}$ (It is also worthy of note that the very same act excluded the Slavic [i.e., future Slovenian] population in the provinces of Carniola, Gorizia, Carinthia and Styria from the denotative field of "Illyria".) Within this context all future official Roman Catholic institutions, documents and publications used the term "Illyria" and its derivations to denote persons and artefacts springing from the prevalently Catholic population and its culture at the eastern shores of the Adriatic, with its corresponding hinterland up to the Drava River to the north and the Danube and Drina rivers to the east. In this, special importance should be given to the fact that the terms "Illyrian", "Croatian" and "Slavic/Slavonic" were used and interpreted as synonyms from the publication in 1604 of Bartol Kašić's (a.k.a. Bartholomaeus Cassius) first grammar of Croatian, Institutiones linguae illyricae, throughout the seventeenth century with two printed dictionaries and all the way up to the mid-eighteenth century with a further three printed dictionaries. Thus, for example, in his dictionary entitled Blago jezika slovinskoga (Loreto-Ancona, 1649-1651), Jacobus Micalia gives the translation "Illyricus, Croata" for the ethnic name "Hrvat" (a Croatian). Almost one hundred years later, in his dictionary Lexicon Latinum interpretatione Illyrica, Germanica, et Hungarica (Zagreb, 1742) Andrija Jambrešić offered an Appendix entitled Index Illyrico sive Croatico-Latinus; moreover, under the entry "Illyricus" he explains that it is "Illirianski ali Szlovenski, Horvatczki etc." ("Illyrian or Slavonian, Croatian etc.); and in German: "Illyrisch das ist Croatisch, Dalmatinisch etc. oder zum Croaten, Sclavoniern etc. gehörig" ("Illyrian is Croatian, Dalmatian etc. or that which belongs to Croatians, Slavonians etc."). Thus, to cite the prominent contemporary Slavist Radoslav Katičić, it can be stated that

As soon as one takes into account this long and firm tradition of the Illyrian language and the way it was commonly understood up to the $1830 \mathrm{~s} . .$. , it is no more unusual [to

2 Moguš, "Seventeenth and Eighteenth Century Croatian Grammars", 421.

3 Katičić,"Ilirci i ilirski jezik", 682; Moguš, "Seventeenth and Eighteenth Century Croatian Grammars", 421. 
understand] that in those times everybody knew [what was meant] when the Illyrian language was mentioned. ${ }^{4}$

This familiarity of learned people with the interchangeability of the terms "Illyrian", "Croatian" and "Slavic/Slavonic" (with their overlapping semantic clusters denoting the principal connotational component universally labelled "Croatian" from the second half of the nineteenth century to the present) received a further push with events resulting from the Napoleonic Wars. Namely, one of the various short-lived political entities created by Napoleon's drawing of new boundaries was given the name "Illyrian Provinces" (1809-1813). It encompassed some of present-day Slovenia’s territory (Carniola, western Carinthia, Gorizia) and approximately one-half of present-day Croatia's territory (Istria, Dalmatia, parts of inner Croatia and the Military Frontier), with Ljubljana as the capital. Its quasi-mechanical geographical articulation disregarded the previous delineation between Slovenian and Croatian territories and populations, but it left - by some of its innovative and fresh ideas in education, transport and commerce - a prevailingly positive impression, thus helping both the local public imagination and intellectual engagement to preserve the memory of the term and its ethnic/national connotations. (It must be pointed out here that the administrative territory of the "Illyrian provinces" encompassed people of Catholic, Orthodox and Muslim confessions, and of Croatian, Slovenian, Bosnian Muslim and Serbian ethnic and cultural backgrounds, but with a Croatian Catholic majority.) This connotational shift within the semantic cluster of the term "Illyria" could be interpreted as a notional and factual decline in the Roman Catholic seventeenth/eighteenth-century ethnic and religious delimitation between the Catholic Croats and Slovenians to the west, and the Orthodox Serbs and Islamized Bosnians to the east.

Moreover, the idea and socio-political reality, as well as the very use of the term "Illyrian", figured as a prelude to the new political constellations and social realities after the 1814-1815 Congress of Vienna, which introduced a new geo-ethnic pattern in the south-eastern part of the Habsburg Monarchy. The formerly Venetian Dalmatia, the Republic of Ragusa, the Military Frontier and Istria were now administrated directly by the Austrian authorities, and the provinces of Croatia proper and Slavonia came under the stricter Hungarian administration. Perhaps based on the French model (Napoleon's "Illyrian Provinces"), its first administrative form was named the "Kingdom of Illyria"; it was created by the Habsburg Emperor Francis I (II) in 1816 and abolished in 1822.

This whole development, along with some others, inspired Croatian political and intellectual circles to begin "recycling" this ancient term, or re-inventing it as an old/ new construct to be used as a "supra-regional" label acceptable to the majority of the population in the creation of a new Croatian "cultural-national" concept. This was first articulated in the famous Dissertation by Count Janko Drašković, written in Croatian and published in Karlovac in 1832. It consists of political, economic, cultural and, last but not least, linguistic topics, with language being at the core of the "Illyrian" issue. Namely, the question of what languages were used in public affairs of the Habsburg Empire started to

4 Katičić, "Ilirci i ilirski jezik", 676; Moguš, "Seventeenth and Eighteenth Century Croatian Grammars", 421. 
provoke vivid discussions that resulted in long-term consequences. This began in 1784, when Joseph II introduced German as the official language for the territory of the whole multi-ethnic Habsburg Monarchy. ${ }^{5}$ The Hungarian answer came very soon: the joint Diet of Hungary and Croatia, held in Pressburg/Pozsony (Bratislava), requested as early as 1790 that Hungarian be introduced as the official language for the Kingdom of Hungary, ${ }^{6}$ including Croatian areas. Because "at that time, patriotism was manifested in the public use of the vernaculars, or linguae patriae", the Croatians, or "Croatae, the noble natio politica of the Kingdoms of Dalmatia, Croatia and Slavonia", ${ }^{8}$ initiated political debates with Hungarian politicians on the language issue for the next three decades. Finally, in 1832, it was precisely Count Drašković's Dissertation (aimed at future Croatian delegates to the joint Diet of Hungary and Croatia) that presented the Štokavian dialect as the "Illyrian language" and as a standardized national Croatian language "with a continuity of literature ever since Humanism". This was the argument offered against the 1827 attempt by the joint Diet to introduce Hungarian as an obligatory subject in Croatian institutions, administration and the school system, and to refute the prejudice that the Croatians were a "nation without a mother tongue". ${ }^{9}$ Drašković pointed out the "natural right of nations to cultivate their own language - the "spiritual connection between peoples and countries", and - equally importantly - introduced the "new political concept of the 'Kingdom of Illyria', grounded in historical and natural rights and based on a common language. This construct, which would incorporate Dalmatia, Bosnia, and even the Slovenian provinces, [was] named 'Great Illyria' (Cro. Velika Ilirija)". ${ }^{10}$ Hence, "the 'Dissertation' established itself among the public from the very beginning as the most complete and the most basic program of the whole Romantic movement of [the Croatian] 'national awakening', and as such it became incorporated into the national canon as early as the nineteenth century". ${ }^{11}$

What immediately followed Drašković's initiative were the ideas, writings and actions undertaken by Ljudevit Gaj (1809-1872), which substantially improved and refined the initial impulse. Following his university studies in philosophy and law, undertaken in Vienna, Graz, Pest and Leipzig, he made a name for himself by publishing A Short Foundation of the Slavic-Croatian Orthography (Buda, 1830), which proposed a reformed phonetic orthography based on the one introduced for Czech, which would lay down the foundation of modern Croatian spelling. Equally important was his success in 1835 of publishing the first newspapers with a literary supplement entirely in Croatian. In 1836 he replaced their initial titles of Novine Horvatske (The Croatian Newspaper) and Danica Horvatska, Slavonska i Dalmatinska (The Croatian, Slavonian and Dalmatian Morning Star) with, Ilirske narodne novine (The Illyrian National Newspaper) and Danica ilirska (The Illyrian Morning Star), respectively.

\footnotetext{
5 Discourses, 340.

6 Discourses, 340-341.

7 Discourses, 341.

8 Discourses, 341.

9 Discourses, 342-343.

${ }^{10}$ Discourses, 343.

${ }^{11}$ Discourses, 343-344.
} 
What were the semantic reasons behind this shift? "Since Gaj wanted to address a broader South Slavic literary public, he preferred the neutral and inclusive supra-national historical name 'Illyrian' instead of the too narrow and exclusive 'Croatian"."12 The semantic narrowness of the term "Croatian" at that time (which in its Kajkavian dialect could be applied only to three counties in the "Ban's Croatia") induced Gaj to propose the term "Illyrian" as an artificial construct encompassing all South Slavic dialects, which broadened the basis for the new literature. ${ }^{13}$ Thus the practical tendency to overcome locally patriotic cultural particularisms lead to the proposition of a virtual reunification of the defunct Triune Kingdom of Croatia, Slavonia, and Dalmatia, at least linguistically. It also led to the creation of a single literary language ${ }^{14}$ following the Herderian model created within the context of the early nineteenth-century disunited Germanic lands.

However, the attempts to extend the idea of this linguistic unification to the Slovenian, Serbian and even Bulgarian socio-cultural circles failed, because their scholars and politicians clearly rejected the idea in its very core. ${ }^{15}$

Be that as it may, the term "Illyrian" was accepted in Croatia proper and Slavonia during the 1830s and 1840s, and later also in Dalmatia and Istria, as a nominal label for a series of newly established institutions. Thus, for example, the central cultural institution (which later became what is even today one of the most influential cultural societies in Croatia), established in 1842, was named Matica ilirska (The Illyrian Literary Society); somewhat earlier, in 1838, the first Illyrian Reading-Room was established in Zagreb; in 1842 a German-Illyrian dictionary was published by Ivan Mažuranić and Jakov Užarević; earlier, in 1838, Count Drašković directed a programmatic letter to young Croatian women, calling them "Illyrian daughters"; in 1841 the Illyrian People's Party was established; and in 1846 the department of the Illyrian language was created at the Royal Academy in Zagreb. The overall enthusiasm was of such intensity that political circles in Pest, Vienna and even the Vatican expressed their serious concern about "Illyrian Pan-Slavism" as a threat to stability in central Europe, and so the Viennese authorities officially banned the name and symbols of Illyrism between 1843 and 1845. However, even from 1842 it was already clear to Croatian "awakeners" (i.e., members of the Illyrian National Movement) that the term "Illyrian" should thereafter be used only for denoting the idea of the "ethnic and cultural community" of South Slavic peoples, and that the political drive to unify all the Croatian provinces with the aim of independence should be led under the name "Croatia". ${ }^{16}$

${ }^{12}$ Discourses, 234.

${ }^{13}$ Discourses, 233.

${ }^{14}$ Discourses, 233.

15 The Serbian linguist and lexicographer Vuk Stefanović Karadžić "would be the main oponent of the Illyrian project among the Serbs, which he refuted as early as in 1836 by the text 'Serbs all and everywhere' (Srbi svi i svuda). There he radically rejects the name Illyrian, and extends his concept of Serbianness (one language - one nation) from 'Trieste to the River Bojana in Montenegro, thus renaming the Croatian, Slavonian, Bosnian and Montenegrin nationalities as Serbs. Such ideological permeation of the language, which, by means of 'performative naming' (Bourdieu), ontologically changes the named object (in this case, 'nationalities'), would be the cornerstone of future Croatian-Serbian linguistic clashes.” Discourses, 234.

${ }^{16}$ Stančić, "Pretpreporod i narodni preporod", $60 \rightarrow$ Lj. Vukotinović. 


\section{And what about musical "Illyrism"?}

With regard to musical culture in the Croatian lands, no mention of the term "Illyria" and its derivations in connection with music can be found prior to the nineteenth-century National Movement. Of course, opinions about the peculiar beauty of Croatian folk tunes started to appear publicly from the very beginning of the nineteenth century (e.g., in the newspaper Télégraphe in Ljubljana around 1810, or in Bishop Maksimilijan Vrhovac's order of 1813 to his clergymen in Zagreb to start collecting the treasures of folk music production). Such ideas and actions could be understood as a prelude to one of the "Illyrian" obsessions: the collection of folk tunes, which was pursued in the 1830s and 1840s by Sabo Franković (1830), Stanko Vraz (prior to 1844), Carlo Catinelli-BevilaquaObradić (1847) and others. The term "Illyrian" was extensively used in naming various phenomena in Croatian and primarily Zagreb musical life, including a concert of arias and opera fragments in the "Illyrian language" in 1838; Count Drašković's holding the "first Illyrian musical party" in 1839; the founding of the Narodno ilirsko skladnoglasja društvo (Illyrian People's Music Society) by Zagreb seminarians in 1839; the founding of the Prvo ilirsko glasbeno družtvo (First Illyrian Music Society) by the students of the Zagreb Royal Academy in 1840; and so on. ${ }^{17}$ About one hundred rousing songs have been preserved from the period from 1833-1850, most of them labelled as "Illyrian" both by the intentions of their authors and performers and the audience reception.

Ljudevit Gaj, the leading personality of the Illyrian movement, represents a special case regarding ideas about music. He explicitly wanted a musical setting for his most important literary product, the early poetic-political manifesto Još Hrvatska ni propala dok mi živimo (Croatia Is Not Doomed As Long As We Live) from 1833 to be "national". In 1837 he crystallized this idea as the following:

\footnotetext{
We have laid the foundations for Croatian music and given it direction: let it draw from the people, and when it creates something new, let it also be in the spirit of the people - but not as unadorned and naive as the products of the simple people are, but rather sophisticated, refined, according to the rules of art and aesthetics; thus, we shall achieve what other nations lack: true national music..$^{18}$
}

Within the musical context one outstanding feature can be stated for the entire Illyrian Movement period: the terms "Illyrian", "Croatian" and "national" had been used in music quite freely and practically synonymously. To the contrary, these terms were much more carefully used in politics and literature, with a clear insight into what was "Croatian" and what was "Illyrian" (i.e., belonging to the broader community of other South-Slavic ethnicities). Thus it could be stated that the musicians of the Illyrian period considered themselves "Illyrian" musicians mostly because they were active within the period called "Illyrism", because they used the "Illyrian" language in the songs they composed and performed, and because they declared themselves as ideologically belonging to the

\footnotetext{
${ }^{17}$ Andreis, Music in Croatia, 140-149.

${ }^{18}$ Cited in: Andreis, Music in Croatia, 141-142 (according to Kuhač's Glasbeno nastojanje Gajevih Ilira. Povjestna crtica, Zagreb 1885).
} 
"Illyrian" socio-cultural movement. The aspect of using "Illyrian" folk music material as the basis for their art music was usually articulated within the consciousness that they were using Croatian folk tunes (sometimes in their regional variants).

The "Illyrian" name almost disappeared from public use after 1850. It was to a certain extent replaced by the new term "South-Slavic" or "Yugoslav"; for example, in the title of the Yugoslav Academy of Sciences and Arts, founded in Zagreb in 1866; in the name of the Družtvo za Jugoslavensku pověstnicu i starine (Society for Yugoslav History) and its journal Arhiv za povjestnicu jugoslavensku (Archives of Yugoslav History) published between 1851 and 1875; in Ivan Kukuljević's Slovnik umjetnikah jugoslavenskih (A Dictionary of Yugoslav Artists) from 1858; in the title of Kuhač's epoch-making collection of Južno-slovjenske narodne popievke (South-Slavic Folk Tunes; 1878-1881); and so on. Of these, it was Franjo Ksaver Kuhač, the outstanding ethnomusicologist, music historian and collector of folk tunes, who rehabilitated the term "Illyrian" in 1893, by publishing the important book entitled Ilirski glazbenici. Prilozi za poviest Hrvatskoga preporoda. Glazbotvorci, ishitrioci, pjevači, pjevačice i sakupljači hrv. pučkih popievaka (Illyrian Musicians. A Contribution to the History of the Croatian Revival. Composers, Poets, Male and Female Singers, and the Collectors of Croatian Folk Tunes). It is obvious that here again the terms "Illyrian" and "Croatian" are used as synonyms, and that the syntagm "Illyrian musicians" is used only to define a historical period with a certain dominant ideology ("in the time of Illyrism; that is, between 1835 and 1850" - "u vrieme Ilirizma ili ako ćemo reći od godine 1835 do godine $1850 " 19$ ), and not as an indication of the existence of some imaginary "Illyrian" music as such. It is also interesting to note that the personalities Kuhač listed among Illyrian musicians were selected and presented exclusively by ideological and not national criteria: among the eighteen "Illyrians" cited and elaborated in this book, two were of Austrian origins (Ferdo [Wiesner] Livadić and Karlo von Prandau), two Hungarian (Dragutin von Turányi and Sidonija Rubido Erdödy), two Czech (Vatroslav Vernak and Franjo Pokorni), one Slovenian (Stanko Vraz), one Serbian (Josip Runjanin), and only ten were Croatians (Fortunat Pintarić, Ivan Padovec, Franjo Ksaver Čačković-Vrhovinski, Josip Juratović, Pavao Stoos, Mijo Hajko, Vjekoslav Karas, Ferdo Rusan, Pajo Kolarić and Marijan Jaić). ${ }^{20}$

${ }^{19}$ Kuhač, Ilirski glazbenici, LXIV.

${ }^{20}$ There original presentations in Croatian are as follows: Ferdo Livadić - hrvatski glazbotvorac (Croatian composer); Fortunat Pintarić - crkveni glazbotvorac i orguljaški virtuoz (church composer and organ virtuoso); Ivan Padovec - kitaraški virtuoz i glazbotvorac (guitar virtuoso and composer); Karlo barun Prandau - glazbotvorac (composer); Franjo Ksaver Čačković-Vrhovinski - flautista i hrv. glazbotvorac (flautist and Croatian composer); Josip Juratović - regens chori i crkveni glazbotvorac (choirmaster and church composer); Pavao Stoos - pjesnik i uglazbatelj crkvenih pjesama (poet and arranger of church songs); Dragutin pl. Turanji - glazbotvorac (composer); Mijo Hajko - uglazbatelj hrv. pjesama (arranger of Croatian songs); Vjekoslav Karas - slikar i diletantski glazbotvorac popievaka (painter and amateur composer of songs); Vatroslav Vernak - pjesnik i uglazbatelj hrv. pjesama (poet and arranger of Croatian songs); Franjo Pokorni - glazbotvorac (composer); Ferdo Rusan - pjesnik i ishitrilac pievnih melodija (poet and composer of singable melodies); Josip Runjanin - ishitrilac melodija za hrv. pjesme (inventor of melodies for Croatian songs); Pajo Kolarić - ishitrilac hrv. pievnih melodija i vješt tanburaš (inventor of singable Croatian melodies and skilful tamburitza player); Sidonija 
Kuhač also felt that the most outstanding composer of the Illyrian period was not Vatroslav Lisinski (later named the "founding father" of modern Croatian art music), ${ }^{21}$ but Ferdo Livadić, who

can be named as the first and greatest composer of that Illyria, which was conceived by Napoleon in a political sense, and by Janko Drašković and Ljudevit Gaj in the political and literary sense. And as Gaj set in motion Slavic life in literature, thus Livadić initiated the Slavic idea in music; or, to put it in a different way, Livadić musically embodied Gaj, and he precisely noted the era of awakened Illyrism in music. ${ }^{22}$

\section{Conclusions}

1. The term "Illyrian" is more than two thousand years old, but was not consistently used throughout history: during the Middle Ages it was practically forgotten.

2. Its primary use encompasses the areas of geography, politics, culture and linguistics, denoting the physical and conceptual world along the eastern Adriatic shores and the corresponding hinterland up to the great rivers in the north and east.

3. In music it was used during a much shorter period of time than in literature, linguistics and politics - only during the nineteenth century, notably from 1835-1850.

4. In music it was used as an ideological construct and was extended to a broader denotative field than in other areas - it encompassed an imagined virtual community of all South-Slavic music cultures; its specific continuation was manifested in the SouthSlavic/Yugoslav concept and terminology.

5. In real musical life and practice it was used mostly as a synonym for denoting Croatian art music produced from 1835-1850 within the Croatian National Revival movement.

\section{Bibliography}

Andreis, Josip. “Glazbena kultura u doba narodnog preporoda” [Musical Culture During the National Revival], 177-187. In Povijest hrvatske glazbe [History of Croatian Music]. Zagreb: Liber-Mladost, 1974.

"Ilirski skladatelji (Illyrian Composers)". In Povijest hrvatske glazbe

[History of Croatian Music], 187-223. Zagreb: Liber-Mladost, 1974.

Discourses of Collective Identity in Central and Southeast Europe (1770-1945). Texts and

Commentaries, Vol. II: National Romanticism. The Formation of National Movements, edited by Balázs Trencsényi and Michal Kopeček. Budapest: CEU Press, 2007.

Drašković, Janko. "Dissertation, or Treatise". In Discourses of Collective Identity in

Rubido-Erdödy - prva hrvatska primadonna (first Croatian prima donna); Marijan Jaić - sakupljač i ukajditelj crkvenih pučkih melodija (collector and transcriber of church folk melodies); Stanko Vraz - sakupljač napjeva pučkih popievaka (collector of folk song tunes).

${ }^{21}$ Andreis, Music in Croatia, 159.

${ }^{22}$ Kuhač, Ilirski glazbenici, 5. 
Central and Southeast Europe (1770-1945), edited by Balázs Trencsényi and Michal Kopeček, 339-347. Budapest: CEU Press, 2007.

Gaj, Ljudevit. "Proclamations". In Discourses of Collective Identity in Central and Southeast Europe (1770-1945), edited by Balázs Trencsényi and Michal Kopeček, 230-237. Budapest: CEU Press, 2007.

Katičić, Radoslav. "Ilirci i ilirski jezik" [Illyrians and the Illyrian Language]. Forum 27, no.12 (1988): 675-688.

Kuhač, Franjo Ksaver. Glazbeno nastojanje Gajevih Ilira [The Musical Endeavours of Gaj's Illyrians]. Zagreb: Knjižara Mučnjak-Senftlebenova, 1885.

Ilirski glazbenici. Prilozi za poviest hrvatskog preporoda [Illyrian

Musicians. A Contribution to the History of Croatian Revival], 2nd edition. Zagreb: Hrvatska sveučilišna naklada, 1994 (first edition in 1893).

Lipovčan, Srećko. “'Kroatizam' i 'ilirizam', ili: Što su zapravo htjeli 'preporoditelji’?”

['Croatism' or 'Illyrism', or: What did 'Revivalists' Actually Want?]. In Ferdo Wiesner Livadić. Život $i$ djelo, edited by Vjera Katalinić, 11-20. Zagreb: Croatian Musicological Society, 2003.

Moguš, Milan. "Seventeenth and Eighteenth Century Croatian Grammars". In Croatia in the Baroque and the Enlightenment. A Cultural Survey, edited by Ivan Golub and Stanislav Tuksar, 421-433. Školska knjiga: Zagreb 2015.

Stančić, Nikša. Gajeva "Još Horvatska ni propala” iz 1832-33 [Gaj's "Croatia Hasn't Fallen Yet While We Live" from 1832-33]. Zagreb: Globus - Zavod za hrvatsku povijest Filozofskog fakulteta u Zagrebu, 1989.

"Pretpreporod i narodni preporod" [The Pre-national Revival and the

National Revival]. In Hrvatska i Europa. Kultura, znanost $i$ umjetnost, Vol. IV, edited by Josip Bratulić, Josip Vončina and Antun Dubravko Jelčić, 49-62. Zagreb: Školska knjiga, 2009.

White, Harry and Michael Murphy. Musical Constructions of Nationalism. Essays on the History and Ideology of European Musical Culture 1800-1945. Cork: Cork University Press, 2001.

\section{IZNAJDBA GLASBENEGA ILIRIZMA}

\section{Povzetek}

Da bi pravilno razumeli fenomen »ilirizma« v hrvaški in južnoslovanski glasbeni zgodovini, je potrebno opozoriti na nekatere neglasbene pomene izraza in ideje same v širši zgodovinski perspektivi. Sama ideja »Ilirov« kot slovanskega tipa avtohtonih prebivalcev kontinentalnega področja severovzhodno od jadranske obale izhaja iz splošnega hrvaškega zgodovinopisja zgodnjega novega veka. Pomemben dogodek se je zgodil leta 1655, ko je Rimska cerkev Sancta Rota razglasila »del teritorija, ki obsega Dalmacijo, Hrvaško, Bosno in Slavonijo« za Dalmatia seu Illyricum. S tem so se imena Illyricum (za ozemlje), Iliri (za prebivalstvo) in ilirski (kot pridevnik, ki se nanaša na narodnost, 
jezik itd.) uporabljala $v$ uradnih cerkvenih dokumentih in objavah za označevanje oseb in predmetov teh področij. V skladu s tem so se izrazi »ilirski«, »hrvaški« in »slovanski/ slavonski« pogosto alternativno uporabljali za označevanje fenomenov, ki so se nanašali na zgoraj omenjeni fizični in duhovni prostor. To pojasnjuje, zakaj je bila raba pojma »ilirski« med hrvaškim narodnopreporodnim gibanjem v tridesetih in štiridesetih letih 19. stoletja $v$ intelektualnem in kulturnem krogu med večino prebivalstva že udomačena.

»Ponovni izum« in uporabo izraza »ilirski« v 19. stoletju za hrvaški kulturo in glasbo bi lahko pojasnili tudi s težnjami vodilnih ideologov hrvaškega narodnega preporoda, kot so bili Ljudevit Gaj, Janko Drašković in kasneje (etno)muzikolog Franjo Ksaver Kuhač.

Čeprav je prejšnja raba imena »ilirski« označevala etnično/versko delitev med katoliškimi Hrvati in Slovenci na zahodu ter pravoslavnimi Srbi in islamiziranimi Bosanci na vzhodu, je bil po letu 1815 kot posledica takratne družbenopolitične situacije izdelan nov geo-etnični model južnovzhodnega dela habsburške monarhije: Dalmacija z Dubrovnikom ter vojaško mejno področje in Istra so bili pod avstrijsko, banska Hrvaška in Slavonija pa pod madžarsko upravo. Ta delitev je nujno spodbudila izum in rabo nadregionalnega imena, da bi bila ideja o združitvi podobnih kulturnih (in glasbenih) območij in koncept »kulturne nacije« sprejemljiva za večino prebivalstva. Najprej je bila ta oznaka »ilirski«, konec štiridesetih in v petdesetih letih 19. stoletja pa se je delila v »hrvaški« za ožje področje in »južnoslovanski« ali »jugoslovanski« za pojave, ki so zajeli južnoslovansko prebivalstvo habsburške monarhije (Slovence, Hrvate in delno Srbe).

Ti splošni kulturni in družbeno-politični koncepti so odmevali tudi na glasbenem področju. Ideja zbiranja ljudskih napevov je zaživela že v prvem desetletju 19. stoletja in do zgodnjih osemdesetih let omenjenega stoletja je bilo v epohalni Kuhačevi zbirki zbranih 1600 južnoslovanskih napevov. Glasbeno-ideološka raba zbirke ljudskih pesmi je od štiridesetih let 19. stoletja naprej vidna v prizadevanjih za komponiranje umetne glasbe (pesmi, opera in inštrumentalna glasba Vatroslava Lisinskega in Ivana Zajca) na osnovi izvirne ljudske glasbe in njene izpeljanke, novo-ljudske glasbe. S tem se je, v zvezi z vprašanjem »ilirskega«, folklorno gradivo pretežno hrvaškega izvora alternativno uporabljalo z drugimi južnoslovanskimi ljudskimi glasbenimi idiomi. Ta situacija se je v hrvaški glasbeni kulturi nadaljevala še do dvajsetih in tridesetih let 20. stoletja v delih pretežno neo-nacionalnega glasbenega sloga.

$\mathrm{Na}$ kratko, »glasbeni ilirizem « je bil tako ideološki konstrukt kot tudi realni produkt širšega hrvaškega in delno južnoslovanskega kulturnega in družbeno-političnega procesa v 19. stoletju, ki se je pojavil in izginil znotraj zgodovinskega okvira. 